\title{
Breast Cancer cN3c TNM Finding v6 and v7
}

National Cancer Institute

\section{Source}

National Cancer Institute. Breast Cancer cN3C TNM Finding v6 and v7. NCI Thesaurus.

Code C73355.

Breast cancer with metastasis in ipsilateral supraclavicular lymph node(s). (from AJCC 6th and 7th Eds.) 